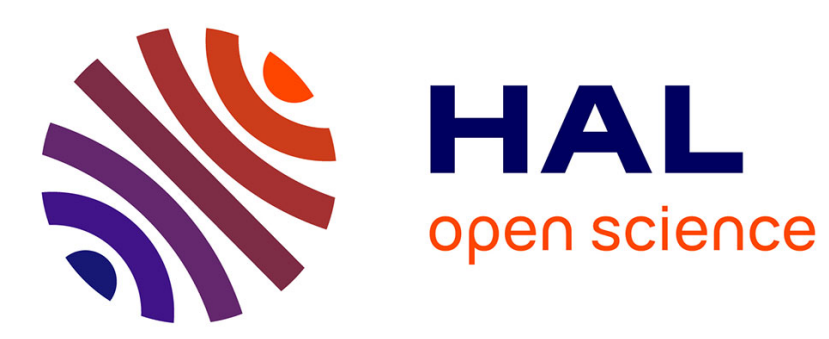

\title{
A luminescent ATCUN peptide variant with enhanced properties for copper(II) sensing in biological media
}

Enrico Falcone, Bertrand Vileno, Mai Hoang, Laurent Raibaut, Peter Faller

\section{To cite this version:}

Enrico Falcone, Bertrand Vileno, Mai Hoang, Laurent Raibaut, Peter Faller. A luminescent ATCUN peptide variant with enhanced properties for copper(II) sensing in biological media. Journal of Inorganic Biochemistry, 2021, 221, pp.111478. 10.1016/j.jinorgbio.2021.111478 . hal-03331614

\section{HAL Id: hal-03331614 \\ https://hal.science/hal-03331614}

Submitted on 1 Sep 2021

HAL is a multi-disciplinary open access archive for the deposit and dissemination of scientific research documents, whether they are published or not. The documents may come from teaching and research institutions in France or abroad, or from public or private research centers.
L'archive ouverte pluridisciplinaire $\mathbf{H A L}$, est destinée au dépôt et à la diffusion de documents scientifiques de niveau recherche, publiés ou non, émanant des établissements d'enseignement et de recherche français ou étrangers, des laboratoires publics ou privés. 


\title{
A luminescent ATCUN peptide variant with enhanced properties for Copper(II) sensing in biological media
}

\author{
Enrico Falcone, ${ }^{\mathrm{a}, *}$ Bertrand Vileno, ${ }^{\mathrm{a}, \mathrm{b}}$ Mai Hoang, ${ }^{\mathrm{a}, \mathrm{c}}$ Laurent Raibaut ${ }^{\mathrm{a}}$ and Peter Faller ${ }^{\mathrm{a}, *}$ \\ ${ }^{a}$ Institut de Chimie, UMR 7177, CNRS, Université de Strasbourg, 4 Rue Blaise Pascal 67000, Strasbourg, France \\ ${ }^{b}$ French EPR Federation of Research, Fédération IR-RPE CNRS, 67081 Strasbourg, France \\ ${ }^{c}$ Department of Chemistry, Earlham College, 801 National Road West, Richmond, 47374, Indiana USA \\ *email address: efalcone@unistra.fr (E.Falcone),pfaller@unistra.fr (P.Faller)
}

\begin{abstract}
The measurement of labile $\mathrm{Cu}^{\mathrm{II}}$ in biological samples is fundamental for understanding $\mathrm{Cu}$ metabolism and has been emerging as a promising diagnostic marker for $\mathrm{Cu}$-related pathologies such as Wilson's and Alzheimer's diseases. The use of fluorescent chelators may be useful to circumvent separation steps employed by current methods. For this purpose, we recently designed a selective and suited-affinity turn-off luminescent probe based on a peptide bearing the $\mathrm{Cu}^{\mathrm{II}}$-binding $X x x-Z z z-H i s$ (Amino-Terminal $\mathrm{Cu}^{\mathrm{II}}$ - and $\mathrm{Ni}^{\mathrm{II}}$-binding, ATCUN) motif and a $\mathrm{Tb}^{\mathrm{III}}$-DOTA (1,4,7,10-tetraazacyclododecane-1,4,7,10-tetraacetic acid) complex. Here, we present an analogue probe bearing the ATCUN motif variant Xxx-His-His. This probe showed much faster response in biologically-relevant media and higher stability than the previous motif at low $\mathrm{pH}$. These features could be beneficial to the measurement of dynamic $\mathrm{Cu}^{\mathrm{II}}$ fluctuations and the application in slightly acidic media, such as urine.
\end{abstract}

\section{Keywords}

Exchangeable Copper(II), ATCUN, lanthanides, luminescence, kinetics, probes

\section{Abbreviations}

AD, Alzheimer's disease; Alloc, allyloxycarbonyl; ATCUN, amino-terminal $\mathrm{Cu}^{\mathrm{II}}$ - and $\mathrm{Ni}^{\mathrm{II}}$ binding; Boc, tert-butyloxycarbonyl; $\mathrm{Cu}_{\mathrm{EXC}}$, exchangeable copper; DCM, dichloromethane; DIEA, N,N-diisopropylethylamine; DMF, N,N-dimethylformamide; DOTA, 1,4,7,10tetraazacyclododecane-1,4,7,10-tetraacetic acid; EDTA, ethylenediaminetetraacetic acid; ESI, electrospray ionization; EPR, electron paramagnetic resonance; ESI, electrospray ionization; FBS, fetal bovine serum; Fmoc, 9-fluorenylmethoxycarbonyl; HCTU, O-(1H-6Chlorobenzotriazole-1-yl)-1,1,3,3-tetramethyluronium hexafluorophosphate; HEPES, 4-(2hydroxyethyl)-1-piperazineethanesulfonic acid; HPLC, High Performance Liquid Chromatography; HSA, human serum albumin; ${ }^{\mathrm{c}} K_{7.4}$, conditional stability constant at $\mathrm{pH} 7.4$; LB, lysogeny broth; LOD, limit of detection; LT, low temperature; MS, mass spectrometry; PyBOP, (Benzotriazol-1-yloxy)tripyrrolidino-phosphonium-hexafluorophosphate; ROS, reactive oxygen species; $\mathrm{RT}$, room temperature; tBu, tert-Butyl; TNBS, 2,4,6Trinitrobenzenesulfonic acid; Trt, trityl; WD, Wilson's disease. 


\section{Introduction}

Most living organisms need copper to survive, owing to its involvement as a redox cofactor in essential biochemical processes, such as cellular respiration. Besides, an ensemble of $\mathrm{Cu}^{\mathrm{II}}$ carriers has evolved to cope with the potential toxicity of loosely bound $\mathrm{Cu}$, which is prone to catalyse the production of Reactive Oxygen Species (ROS) and to induce protein mis/transmetallation and aggregation.[1] Clearly, the failure of $\mathrm{Cu}$ homeostasis may lead to pathological conditions. For instance, the so-called Menkes and Wilson's diseases are genetic disorders arising from mutations of the $\mathrm{Cu}$ membrane transporters ATP7A and ATP7B, which result in a systemic $\mathrm{Cu}$ deficiency or tissue-dependent $\mathrm{Cu}$ accumulation, respectively.[2-4] In addition, $\mathrm{Cu}$ dyshomeostasis has also been reported in neurodegenerative diseases, cancer and diabetes.[5-7] As a result, alteration of $\mathrm{Cu}^{\mathrm{II}}$ levels and speciation in body fluids is often observed in Cu-related diseases.[8]

Physiological $\mathrm{Cu}$-complexes can be distinguished into "inert" and "exchangeable" pools depending on their kinetic lability. In the blood, cuproenzymes, such as Ceruloplasmin, are typically inert, while $\mathrm{Cu}^{\mathrm{II}}$-carriers, such as Human Serum Albumin (HSA) and amino acids, can exchange $\mathrm{Cu}$ with each other and possibly with suitable exogenous chelators.[8,9] Interestingly, in Wilson's disease (WD) and Alzheimer's disease (AD), increased levels of the exchangeable $\mathrm{Cu}\left(\mathrm{Cu}_{\mathrm{EXC}}\right)$ in blood serum have been proposed as a potential diagnostic marker.[10,11] Therefore, methods for $\mathrm{Cu}_{\mathrm{EXC}}$ measurement are currently under development. To date, most methods rely on the separation of $\mathrm{Cu}_{\mathrm{EXC}}$ from the inert pool prior to $\mathrm{Cu}$ analysis by inductively coupled plasma-mass spectrometry or atomic absorption spectroscopy, even when an exogenous chelator (e.g., ethylenediaminetetraacetic acid, EDTA) is used to extract $\mathrm{Cu}$ from the exchangeable pool.[8] Unfortunately, such separation steps have been shown to undermine reliability and reproducibility.[12,13] In order to circumvent this issue, a "smart" chelator may be used as $\mathrm{Cu}^{\mathrm{II}}$-probe in a biological sample, exploiting, for instance, its fluorescent emission.[14] However, this approach requires some important restrictions in the design of the probe. In particular, the main requisites are (i) high selectivity over other physiological metal ions (especially $\mathrm{Zn}^{\mathrm{II}}$, as it is more available than $\mathrm{Cu}^{\mathrm{II}}$, and the most similar to $\mathrm{Cu}^{\text {II }}$ in term of coordination properties), (ii) a suited affinity, e.g. a conditional stability constant at pH $7.4\left(\log { }^{c} K_{7.4}\right)$ higher than HSA $(\approx 13)$ for application in the blood, and (iii) a signal-to-noise ratio apt to measure relatively low sensor concentrations (e.g. lower than $\approx 10$ $\mu \mathrm{M}$ to ensure a significant $\mathrm{Cu}$-loading in the blood, where $\mathrm{Cu}_{\mathrm{EXC}}$ is at most $\approx 5 \mu \mathrm{M}$ ) despite high signal background, such as autofluorescence.[8] For this purpose, we recently developed a luminescent peptide probe, hereafter denoted $\mathbf{G N H}^{\mathbf{W} / \mathbf{T b}}$, bearing the Amino-Terminal $\mathrm{Cu}^{\mathrm{II}}$ and $\mathrm{Ni}^{\mathrm{II}}$-binding (ATCUN) motif and a Tb ${ }^{\mathrm{III}}$-DOTA (1,4,7,10-tetraazacyclododecane-1,4,7,10tetraacetic acid) complex. $\mathbf{G N H}^{\mathbf{W} / \mathbf{T b}}$ benefits from the specificity and the suited affinity of the ATCUN motif and the long-lived luminescence of $\mathrm{Tb}^{\mathrm{III}}(\tau \approx 2 \mathrm{~ms})$, which allowed the detection of $\mathrm{Cu}^{\mathrm{II}}$ in biologically-relevant media, despite strong autofluorescence, via time-delayed luminescence detection (see Fig. 1).[15] The naturally-occurring ATCUN peptide motif, $X x x^{1}$ $\mathrm{Zzz}^{2}-\mathrm{His}^{3}(\mathrm{XZH})$, binds $\mathrm{Cu}^{\mathrm{II}}$ in a square-planar site via the $\mathrm{N}$-terminal amine, the first two amidates of the peptide backbone, and the imidazole $\mathrm{N}^{\pi}$ of $\mathrm{His}^{3}$ (see Fig. 2). The thermodynamic and kinetic stability of ATCUN complexes depends on the identity of $X x x, Z z z$ and the sequence downstream $\mathrm{His}^{3}{ }^{3}$ [16] For instance, $\mathrm{Cu}^{\mathrm{II}}$ binds to HSA motif (Asp-Ala-His-, 
DAH-) with $\log { }^{\mathrm{c}} K_{7.4}=13$, while it binds to Neuromedin C, whose Gly-Asn-His-Trp (GNHW) motif was adopted in the probe $\mathbf{G N H}{ }^{\mathbf{W} / \mathbf{T b}}$, with $\log { }^{\mathrm{c}} K_{7.4}=13.6$. [17,18] $\mathrm{Cu}^{\mathrm{II}}-\mathrm{XZH}$ complexes are stable over a large $\mathrm{pH}$ range, classically from above $\mathrm{pH} 10$ down to about 5.5, where decoordination starts to occur.[19-21] Importantly, $\mathrm{Zn}^{\mathrm{II}}$ does not seem able to bind to the ATCUN motif (at least at $\mathrm{pH}<9$ ), due to its lower Lewis acid character (crucial to favour the deprotonation of the two amide groups) and the preference for tetrahedral rather than planar coordination geometry.[19,22]

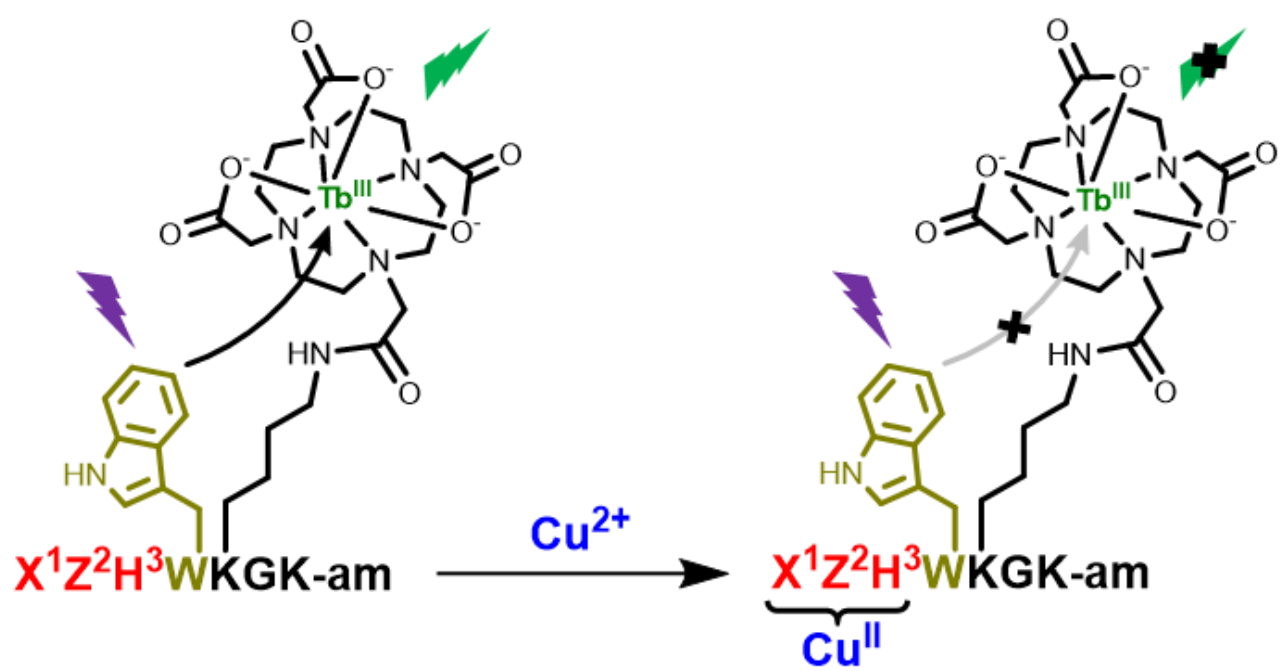

Figure 1. Schematic mechanism of $\mathrm{Cu}^{\mathrm{II}}$ sensing by $\mathbf{X Z \mathbf { Z H } ^ { \mathrm { W } } / \mathrm { Tb }}$ peptides: $\mathrm{Tb}^{\mathrm{III}}$ emission after Tryptophan (dark yellow) excitation (purple) and energy transfer ("antenna effect") is quenched by $\mathrm{Cu}^{\mathrm{II}}$ binding to the ATCUN motif (red).

From the kinetic point of view, $\mathrm{Cu}^{\mathrm{II}}$ binding to $\mathbf{G N H}^{\mathrm{W} / \mathrm{Tb}}$ in HEPES (4-(2-hydroxyethyl)-1piperazineethanesulfonic acid) buffer was fast, i.e., complete in the mixing time. On the opposite, $\mathrm{Cu}^{\mathrm{II}}$ binding to $\mathbf{G N H}^{\mathbf{W} / \mathbf{T b}}$ in $10 \%$ Lysogeny Broth (LB, a medium for bacterial cell culture) revealed to be rather slow (approximately $50 \% \mathrm{Cu}^{\mathrm{II}}$ binding to the probe was achieved within two hours), likely because of the presence of many kinetically-competing binding sites in the medium (composed of tryptone and yeast extract) with slow $\mathrm{Cu}^{\mathrm{II}}$ transfer to the probe's ATCUN motif.[15] Such slow responsiveness of the probe in a complex biological medium may represent an important drawback for practical applications, especially if the detection of fast dynamic $\mathrm{Cu}^{\mathrm{II}}$ fluctuations is sought. Here, we aim to improve the kinetic response of the probe by means of the $X x x^{1}-H_{i}^{2}-H i s^{3}$ (XHH) ATCUN variant, which has shown a faster $\mathrm{Cu}^{\mathrm{II}}$ exchange. The $\mathrm{Ala}^{1}-\mathrm{His}^{2}-\mathrm{His}^{3}$ (AHH) motif has been recently investigated thoroughly.[23,24] At $\mathrm{pH}$ 7.4, AHH motif binds $\mathrm{Cu}^{\mathrm{II}}$ with the ATCUN 4N $\left(\mathrm{NH}_{2}, \mathrm{~N}^{-}, \mathrm{N}^{-}, \mathrm{N}_{\mathrm{Im}}\right)$ coordination mode, whereas at $\mathrm{pH}<5.5, \mathrm{Cu}^{\mathrm{II}}$ is mostly coordinated with a $3 \mathrm{~N}\left(\mathrm{NH}_{2}, \mathrm{~N}^{-}, \mathrm{N}_{\mathrm{Im}}\right)$ mode, including the $\mathrm{N}$-terminus, the first amidate and the imidazole $\mathrm{N}^{\pi}$ from $\mathrm{His}^{2}$ (see Fig. 2). Noteworthy, also such $3 \mathrm{~N}$ XH motif is highly selective for $\mathrm{Cu}^{\mathrm{II}}$ (e.g. the $\log { }^{\mathrm{c}} K_{7.4}$ of $\mathrm{AH}$ dipeptide is $\approx 3$ for $\mathrm{Zn}^{\mathrm{II}}$ and $\approx 13$ for $\left.\mathrm{Cu}^{\mathrm{II}}\right)$.[19,25] An external ligand, such as water, completes the square-planar coordination sphere. However, at higher $\mathrm{pH}$, a small portion of such $3 \mathrm{~N}$ coordination mode also co-exists with the predominant ATCUN-type species if excess peptide or a second ligand $\mathrm{L}$ is present, which replace water forming a ternary complex with " $3 \mathrm{~N}+\mathrm{L}$ " coordination mode (see Fig. 2). For instance, a second peptide molecule can provide an imidazole moiety as an 
external fourth ligand, forming a self-ternary complex. Likewise, buffers or other N-containing ligands, such as histidine residues in peptides and proteins, may act as L. Evidently, the percentage of $3 \mathrm{~N}+\mathrm{L}$ species increases at increasing $\mathrm{L}$ concentration. Indeed, self-ternary complexes are negligible $(<1 \%)$ at $\mu \mathrm{M}$ peptide concentration used for luminescence measurements, whereas $\mathrm{mM}$ concentration of external ligands, such as imidazole, can yield comparable populations of the $4 \mathrm{~N}$ and $3 \mathrm{~N}+\mathrm{L}$ species.[23,24] Importantly, the presence of such $3 \mathrm{~N}+\mathrm{L}$ ternary species is held accountable for the higher $\mathrm{Cu}^{\mathrm{II}}$ exchange rate shown by the $\mathrm{AHH}$ motif with respect to its parent AAH.[23] Indeed, the $\mathrm{Cu}^{\text {II }}$-transfer between the ATCUN (XZH) motif and a partner biomolecule (L) seems to occur via a transient ternary complex, which is a transition state where $\mathrm{Cu}^{2+}$ is bound partially to $\mathrm{XZH}$ and partially to $\mathrm{L}$. [26] In particular, a $2 \mathrm{~N}\left(\mathrm{NH}_{2}, \mathrm{~N}_{\mathrm{Im}}\right)$ species has been recently identified as intermediate in the $\mathrm{Cu}^{\mathrm{II}}$ self-exchange of ATCUN complexes.[27] It can be speculated that an analogous (2N)- $\mathrm{Cu}^{\mathrm{II}}-\mathrm{L}$ acts as an intermediate in the $\mathrm{Cu}^{\mathrm{II}}$-transfer between $\mathrm{XZH}$ and $\mathrm{L}$. To date, both the protonation of the amide groups and the overall rearrangement of the ligands around $\mathrm{Cu}^{\mathrm{II}}$ have been proposed as limiting step in the formation of such transition state.[27] Notably, the canonical XZH motif has to de-coordinate and protonate two amidates to form the supposed transition state ternary complex. Instead, the XHH variant can form the $3 \mathrm{~N}+\mathrm{L}\left(\mathrm{NH}_{2}, \mathrm{~N}^{-}, \mathrm{N}_{\mathrm{Im}}, \mathrm{L}\right)$ ternary species (despite its low abundance at $\mathrm{pH} \approx 7$ ), where $\mathrm{L}$ is already bound to $\mathrm{Cu}^{2+}$ and only one amidate has to de-coordinate to reach the transition state. Therefore, the lower number of amide groups to protonate and the presence of $\mathrm{L}$ in the coordination sphere could reduce the activation energy and hence increase the $\mathrm{Cu}^{\mathrm{II}}$-transfer rate of $\mathrm{XHH}$ with respect to $\mathrm{XZH}$. Here, we introduce a new luminescent $\mathrm{Cu}^{\mathrm{II}}$ probe based on the $\mathrm{AHH}$ motif, $\mathbf{A H} \mathbf{H}^{\mathrm{W} / \mathrm{Tb}}$. This sensor variant procures additional advantageous features, namely enhanced kinetic responses in physiologicallyrelevant conditions and broader $\mathrm{pH}$-independence with respect to the former $\mathbf{G N H}^{\mathbf{W} / \mathbf{T b}}$ probe. Moreover, we evaluated the potential interference of external ligands on $\mathrm{Cu}^{\mathrm{II}}$-detection by $\mathbf{A H H}^{\mathrm{W} / \mathrm{Tb}}$.
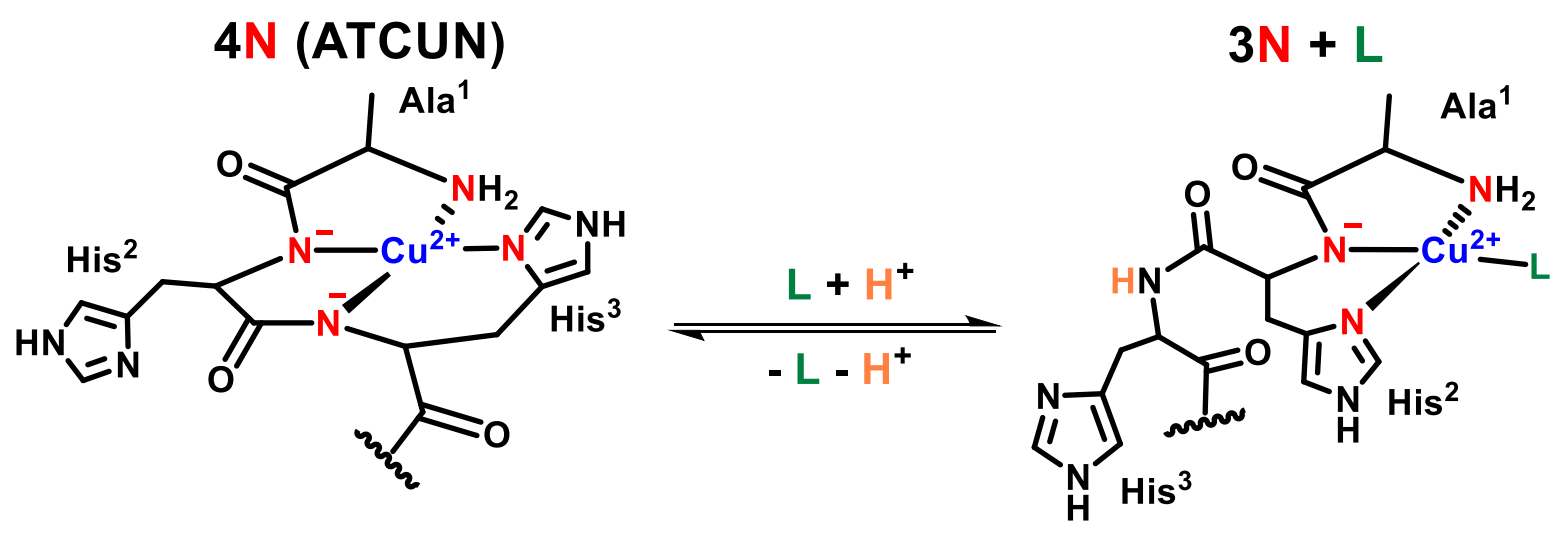

Figure 2. Ala-His-His peptide can bind $\mathrm{Cu}^{\mathrm{II}}$ with $4 \mathrm{~N}$ (ATCUN) or $3 \mathrm{~N}+\mathrm{L}$ coordination modes, depending on the $\mathrm{pH}$ and the presence of external ligands (L). At high $\mathrm{pH}$ and in the absence of external ligands, the $4 \mathrm{~N}$ species is predominant, whereas low $\mathrm{pH}(<5.5)$ and high $\mathrm{L}$ concentration favour the switch to $3 \mathrm{~N}+\mathrm{L}$ coordination. 


\section{Experimental}

\subsection{Materials}

Commercially available reagents were used unless otherwise stated. Essentially fatty acid-free HSA (Sigma) was used without further purification. LB medium was prepared from LB broth (Lennox) powder (Carl Roth), enriched with $5 \mathrm{~g} / \mathrm{L}$ of yeast extract (Carl Roth).

\subsection{Peptide Synthesis}

The peptide $\mathbf{G N H}^{\mathbf{W} / \mathbf{T b}}\left(\mathrm{GNHWK}^{\mathrm{DOTA}(\mathrm{Tb})} \mathrm{GK}-\mathrm{NH}_{2}\right.$ ) was synthesized as previously reported.[15] The peptide $\mathbf{A H H}{ }^{\mathbf{W} / \mathbf{T b}}\left(\mathrm{AHHWK}{ }^{\mathrm{DOTA}(\mathrm{Tb})} \mathrm{GK}-\mathrm{NH}_{2}\right.$ ) was synthesized manually through a standard Fmoc (9-fluorenylmethoxycarbonyl)/tBu solid-phase peptide synthesis (see Fig. S1). In order to obtain a C-terminal-amidated peptide, a Fmoc-Rink amide aminomethylpolystyrene resin (Fmoc-Rink-Amide AM Resin from Iris Biotech, $0.74 \mathrm{mmol} / \mathrm{g}$ loading, 100200 mesh) was used as solid support. Amino acid (4 eq.) coupling was performed at room temperature for about 45 minutes, using O-(1H-6-Chlorobenzotriazole-1-yl)-1,1,3,3tetramethyluronium hexafluorophosphate (HCTU, 3.9 eq.) as coupling agent, N,Ndiisopropylethylamine (DIEA, 8 eq.) as base and N,N-dimethylformamide (DMF) as the solvent. After coupling, the presence of unreacted $\mathrm{N}$-terminal free amine was checked with TNBS (2,4,6-Trinitrobenzenesulfonic acid) reagent, and the coupling was repeated in case of a positive test. Capping of the unreacted free amine group was carried out using $5 \%$ acetic anhydride and 10\% DIEA in DMF for 5 min. N-terminal Fmoc deprotection was carried out using $20 \%$ piperidine in DMF. Lys ${ }^{5}$ was added as $\mathrm{N}^{\varepsilon}$-allyloxycarbonyl-protected (FmocLys(Alloc)-OH) to allow specific side-chain deprotection and following conjugation with DOTA-tris $(t \mathrm{Bu})$ ester. The N-terminal Ala residue was introduced as tert-butyloxycarbonylprotected aminoacid (Boc-Ala-OH) to ensure orthogonal deprotection of the Lys(Alloc). Removal of the $\mathrm{N}^{\varepsilon}$-Alloc protecting group was performed using $\mathrm{Pd}\left(\mathrm{PPh}_{3}\right)_{4}(0.05 \mathrm{mmol}, 0.5$ eq., $58 \mathrm{mg}$ ) and phenylsilane (2.4 mmol, 24 eq., $0.3 \mathrm{~mL})$ in degassed anhydrous dichloromethane $(\mathrm{DCM})$ in the dark $(2 \times 1 \mathrm{~h})$. The resin was then washed with DCM $(2 \times 2 \mathrm{~min}), \mathrm{DMF}(2 \times 2 \mathrm{~min})$, $1 \% \mathrm{H}_{2} \mathrm{O}$ in DMF $(2 \times 2 \mathrm{~min}), \mathrm{DMF}(2 \times 2 \mathrm{~min}), 1 \%$ DIEA in DMF $(2 \times 2 \mathrm{~min}), \mathrm{DMF}(2 \times 2 \mathrm{~min})$, sodium diethyldithiocarbamate in $\operatorname{DMF}(0.12 \mathrm{M}, 2 \times 5 \mathrm{~min})$ and DMF $(2 \times 2 \mathrm{~min})$. DOTA coupling was performed overnight adding DOTA-tris $(t \mathrm{Bu})$ ester $(0.1 \mathrm{mmol}, 57 \mathrm{mg}, 1 \mathrm{eq})$, (Benzotriazol-1-yloxy)tripyrrolidino-phosphonium-hexafluorophosphate (PyBOP, $0.2 \mathrm{mmol}$, $104 \mathrm{mg}, 2$ eq.) and then DIEA ( $0.8 \mathrm{mmol}, 140 \mu \mathrm{L}, 8$ eq.) in DMF. The peptide was cleaved and acid-labile side-chain deprotected by treatment with trifluoroacetic acid/triisopropylsilane/ $\mathrm{H}_{2} \mathrm{O}(95: 2.5: 2.5)$ for $90 \mathrm{~min}$. The crude was precipitated with cold ether and purified by reverse-phase HPLC on a C18 column (XBridge Peptide BEH C18 OBD Prep Column from Waters, $19 \mathrm{~mm}$ x $150 \mathrm{~mm}$, pore size $130 \AA$, particle size $5 \mu \mathrm{m}$ ) using a LaPrep Sigma (VWR International) instrument with UV-vis detection at $214 \mathrm{~nm}$. Tb ${ }^{\mathrm{III}}$ complex was prepared by overnight incubation of the peptide with $\mathrm{TbCl}_{3} \cdot 6 \mathrm{H}_{2} \mathrm{O}\left(5\right.$ eq.) in $\mathrm{H}_{2} \mathrm{O}$ at $\mathrm{pH} \approx 6.3$. Purity and identity of the peptide were assessed by analytical HPLC and ESI-MS (see Fig. S2):

$\mathrm{AHH}^{\mathrm{W}}$, experimental $\mathrm{m} / \mathrm{z}=1248.87$, calculated $\mathrm{m} / \mathrm{z}=1248.84 ; \mathrm{AHH}^{\mathrm{W} / \mathrm{Tb}}$, experimental $\mathrm{m} / \mathrm{z}=$ 1404.82, calculated $\mathrm{m} / \mathrm{z}=1404.76$. Yield: $27 \%$. 


\subsection{Preparation of stock solutions}

All stock solutions were prepared in ultrapure water $\left(\rho=18.2 \mathrm{M} \Omega \cdot \mathrm{cm}^{-1}\right)$. The concentration of peptide stock solutions was determined by tryptophan UV-vis absorption $\left(\varepsilon_{280}=5690 \mathrm{M}^{-}\right.$ ${ }^{1} \mathrm{~cm}^{-1}$ ) and spectrophotometric titration with $\mathrm{Cu}^{2+}$ (see Fig. S3). A stock solution of HEPES buffer (500 mM, pH 7.4) was prepared dissolving free acids in Milli-Q water and adjusting the $\mathrm{pH}$ with $\mathrm{NaOH}$. The concentration of $\mathrm{CuCl}_{2} \cdot 2 \mathrm{H}_{2} \mathrm{O}$ stock solution was verified by $\mathrm{UV}-\mathrm{Vis}$ spectroscopy $\left(\varepsilon_{780}=12 \mathrm{M}^{-1} \mathrm{~cm}^{-1}\right)$. The total concentration of HSA solution was determined using $\varepsilon_{280}=33000 \mathrm{M}^{-1} \mathrm{~cm}^{-1}$. As the N-terminus of commercial HSA stock is partially truncated (and hence $\mathrm{Cu}^{\mathrm{II}}$ binding to the ATCUN site is abolished),[28] the concentration of the ATCUNbearing HSA was measured via spectrophotometric titration with $\mathrm{Cu}^{2+}$. This concentration was considered in all experiments.

\section{4. $U V$-vis Spectroscopy}

UV-vis spectra were recorded on a Cary 60 spectrophotometer using a $1 \mathrm{~cm}$ path quartz cuvette. Peptide titration with $\mathrm{Cu}^{2+}$ was performed adding small aliquots $(1 \mu \mathrm{L})$ of a $\mathrm{Cu}^{2+}$ solution to a peptide solution $(250 \mu \mathrm{M}, 100 \mu \mathrm{L})$ in HEPES $50 \mathrm{mM}$, pH 7.4 (see Fig. S3). UV-vis spectra of $\mathrm{Cu}^{\mathrm{II}}-\mathrm{AHH}^{\mathrm{W} / \mathrm{Tb}}$ in biological media were obtained adding the pre-formed complex to the medium.

\subsection{Luminescence Spectroscopy}

Luminescence spectra were recorded on a Cary Eclipse (Agilent) fluorescence spectrophotometer using a $1 \mathrm{~cm}$ path quartz cuvette. Samples were excited at $\lambda_{\mathrm{ex}}=280 \mathrm{~nm}$. Time-delayed luminescence spectra were acquired with a time delay of $100 \mu \mathrm{s}$.

$\mathrm{Cu}^{2+}$ titration was conducted adding small aliquots $(5 \mu \mathrm{L})$ of a $\mathrm{Cu}^{2+}$ solution into a peptide solution $(10 \mu \mathrm{M}, 1 \mathrm{ml}$ ) in HEPES $50 \mathrm{mM}$, pH 7.4 (see Fig. S4). pH titrations were performed adding small aliquots of a concentrated $\mathrm{NaOH}$ solution to the peptides/complexes solutions in water. Kinetics of $\mathrm{Cu}^{\mathrm{II}}$-binding in LB medium was monitored via time-delayed luminescence using a Spark (Tecan) plate reader inside a 384 wells microplate. Kinetics of $\mathrm{Cu}^{\mathrm{II}}$ release to EDTA was monitored via tryptophan fluorescence emission using a CLARIOStar Plus (GMB Biotech) plate reader inside a 384 wells microplate, with $\lambda_{\mathrm{ex}}=295 \mathrm{~nm}$ and $\lambda_{\mathrm{em}}=360 \mathrm{~nm}$. Note that $\mathrm{Cu}^{\mathrm{II}}$-binding kinetics in LB medium and FBS were measured adding exogenous $\mathrm{Cu}^{2+}$ to a solution of the peptides in the media.

Due to very long equilibration times, calibration curves have been obtained by adding the preformed $\mathrm{Cu}^{\mathrm{II}}$-complexes (at $10 \mu \mathrm{M}$ final concentration of the peptides and $\mathrm{Cu}^{2+}$ concentration varying from 0.1 to $10 \mu \mathrm{M}$ ) to the buffer/media solution. Luminescence intensity was measured using the following parameters: excitation slit $20 \mathrm{~nm}$, emission slit $10 \mathrm{~nm}$, averaging time 0.1 s. The average intensity at $545 \mathrm{~nm}$ over five measurements was plotted versus the $\mathrm{Cu}^{2+}$ concentration and fitted using linear regression $(\mathrm{y}=k \mathrm{x})$ with fixed intercept (the average intensity of the blank, i.e. the peptides in absence of $\mathrm{Cu}^{2+}$ ). The limit of detection (LOD) was calculated based on $3 \sigma / k$ (where $\sigma$ is the standard deviation of the blank measurements and $k$ is the slope of the linear regression line). 


\subsection{EPR Spectroscopy}

A continuous-wave EPR X-band spectrometer (EMXplus, Bruker Biospin GmbH, Germany) equipped with a high sensitivity resonator (4119HS-W1, Bruker) was employed throughout this study to acquire the field-swept spectra from the aqueous solutions at both room (RT, T = $295 \mathrm{~K} \pm 1 \mathrm{~K}$ ) and low temperature (LT, T = $100 \mathrm{~K}$ ). LT was achieved by a continuous flow liquid nitrogen cryostat.

Samples were prepared in $100 \mathrm{mM}$ HEPES ( $\mathrm{pH} 7.4$ ) at $320 \mu \mathrm{M}$ concentration of the ligands and $300 \mu \mathrm{M} \mathrm{Cu}^{\mathrm{II}}$. RT samples were transferred into $25 \mu \mathrm{L}$ glass capillaries (Hirschmann) and sealed on both ends. LT samples were supplemented by $10 \% \mathrm{v} / \mathrm{v}$ glycerol to ensure a good glassy sample once freeze-quenched in $3 \mathrm{~mm}$ ID quartz tubes (Wilmad LabGlass).

The principal RT experimental parameters were: modulation amplitude $10 \mathrm{G}$, microwave power $10 \mathrm{~mW}$, time constant ca. $80 \mathrm{~ms}$, conversion time ca. $375 \mathrm{~ms} .1000 \mathrm{G}$ were swept in 5 minutes and 5 scans were accumulated. Blank sample (100 mM HEPES at pH 7.4) was used to baseline all spectra. The principal LT experimental parameters were: modulation amplitude $5 \mathrm{G}$, microwave power $0.1 \mathrm{~mW}$, time constant ca. $80 \mathrm{~ms}$, conversion time ca. $200 \mathrm{~ms} .1500 \mathrm{G}$ were swept in 5 minutes and 6 scans were accumulated.

\section{Results and discussion}

\subsection{Kinetics of $C u^{I I}$ transfer in biological media}

The luminescence response of $\mathbf{A H} \mathbf{H}^{\mathbf{W} / \mathbf{T b}}$ to the addition of $\mathrm{Cu}^{2+}$ was assessed via a titration (see Fig. S3), which showed a complete quenching upon saturation of the $\mathrm{Cu}^{\mathrm{II}}$-binding site (at $1: 1\left[\mathrm{Cu}^{2+}\right]:\left[\mathbf{A H H}^{\mathbf{W} / \mathbf{T b}}\right]$ ratio). Following our previous observation of slow response to $\mathrm{Cu}^{\mathrm{II}}$ by $\mathbf{G N H}^{\mathbf{W} / \mathbf{T b}}$ in $10 \%$ LB medium,[15] we monitored the time-dependent response of $\mathbf{A H H}{ }^{\mathbf{W} / \mathbf{T b}}$ in the same medium (Fig. 3A). The comparisons made hereafter are based on the degree of quenching over time, which mirrors the amount of $\mathrm{Cu}^{\mathrm{II}}$-bound to the probes. This response is an apparent kinetics dependent on the $\mathrm{Cu}^{\mathrm{II}}$-exchange rate and the affinity of the probes. Remarkably, $\mathbf{A H H}{ }^{\mathbf{W} / \mathbf{T b}}$ showed much faster response than $\mathbf{G N H}^{\mathbf{W} / \mathbf{T b}}$. In order to explore the competitiveness of the probes in the presence of biological $\mathrm{Cu}^{\mathrm{II}}$-ligands and to compare their kinetic response in a simpler system, we investigated the ability of the probes to compete with Human Serum Albumin (HSA), the most abundant component of the $\mathrm{Cu}_{\mathrm{EXC}}$ pool in the blood (see Fig. 3B). Both ligands were able to withdraw $\mathrm{Cu}^{\mathrm{II}}$ from $\mathrm{HSA}$ at equimolar concentration, in agreement with the higher conditional stability constant of the probe motifs compared to HSA (see 1. Introduction). In particular, $\mathbf{A H} \mathbf{H}^{\mathbf{W} / \mathbf{T b}}$ showed higher $\mathrm{Cu}^{\mathrm{II}}$-binding ( $\approx 60 \%$ quenching) than $\mathbf{G N H}^{\mathbf{W} / \mathbf{T b}}(\approx 20 \%$ quenching $)$ after $30 \mathrm{~min}$ incubation. Although the probes compete with HSA at 1:1 ratio, the physiological concentration of HSA in the blood is much higher than the concentration of $\mathrm{Cu}$ and the probe (HSA is normally loaded at $<2 \%$ with $\mathrm{Cu}$ ).[29] Therefore, we tested the probes in a more physiologically-relevant system, i.e. 10\% fetal bovine serum (FBS), a common supplement for cell culture growth media, where the concentration of the endogenous competing ligands exceeds that of probe (e.g. the concentration of bovine serum albumin is $\approx 50 \mu \mathrm{M}$ in $10 \%$ FBS). Thus, we measured the luminescence quenching of the probes upon addition of $\mathrm{Cu}^{2+}$ in the presence of $10 \%$ FBS (Fig. $3 \mathrm{C})$. This medium revealed to be much more competitive than those studied previously, and 
very low and slow $\mathrm{Cu}^{\mathrm{II}}$ binding to both probes was observed $\left(\approx 10 \%\right.$ quenching for $\mathbf{G N H}{ }^{\mathbf{W} / \mathbf{T b}}$ and $\approx 30 \%$ quenching for $\mathbf{A} \mathbf{H H}^{\mathbf{W} / \mathbf{T b}}$ in $30 \mathrm{~min}$ ). Nevertheless, $\mathbf{A} \mathbf{H H}^{\mathbf{W} / \mathbf{T b}}$ showed again faster response. Furthermore, the ability of the probes to release $\mathrm{Cu}^{\mathrm{II}}$, which is useful to monitor dynamic $\mathrm{Cu}$ fluctuations, was studied by competition with a stronger chelator. For this purpose, we monitored the kinetics of $\mathrm{Cu}^{\mathrm{II}}$ transfer between the probes and EDTA $\left(\log { }^{\mathrm{c}} K_{7.4}=15.9\right)$.[30] $\mathbf{A H H}^{\mathbf{W} / \mathbf{T b}}$ showed also a faster release of $\mathrm{Cu}^{\mathrm{II}}$ than $\mathbf{G N H}^{\mathbf{W} / \mathbf{T b}}$ in the presence of $10 \mathrm{mM}$ EDTA (see Fig. 3D). However, no significant difference was observed when $100 \mu$ M EDTA was used (data not shown). Such concentration-dependence suggests that $\mathbf{A H} \mathbf{H}^{\mathbf{W} / \mathbf{T b}}$ showed faster release only when EDTA concentration was high enough to form (transient) ternary complexes with $\mathrm{Cu}^{\mathrm{II}}-\mathbf{A H H}{ }^{\mathrm{W} / \mathbf{T b}}$. Overall, $\mathbf{A H} \mathbf{H}^{\mathrm{W} / \mathbf{T b}}$ showed faster $\mathrm{Cu}^{\mathrm{II}}$ transfer than $\mathbf{G N H}^{\mathbf{W} / \mathbf{T b}}$.

A) Cull binding in $10 \%$ LB medium

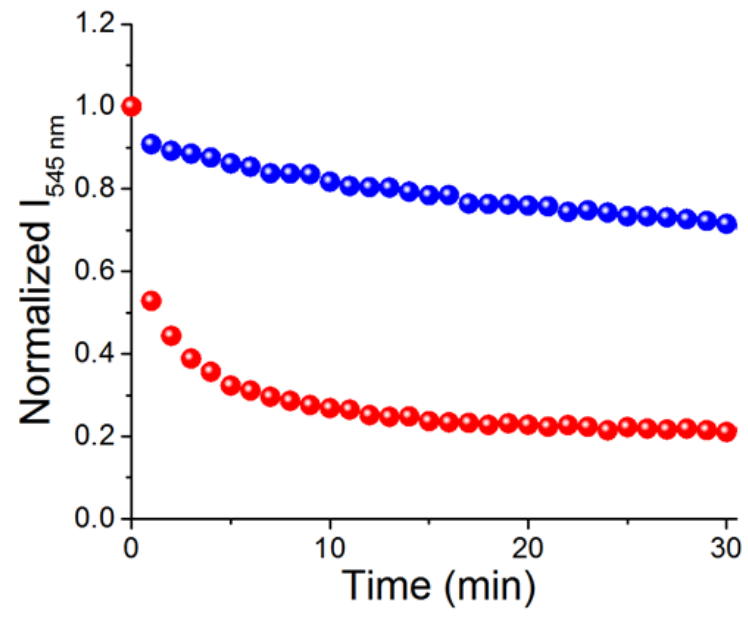

C) Cull binding in $10 \%$ FBS

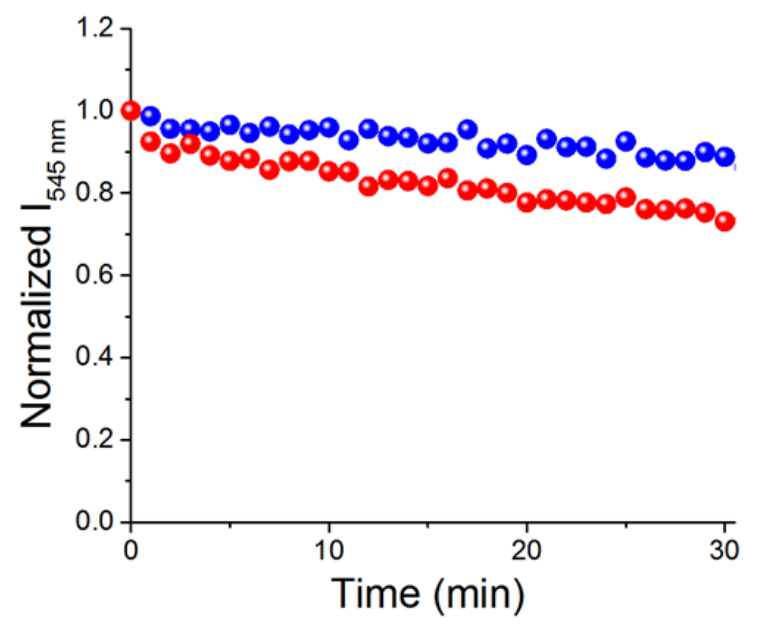

B) Cull transfer from HSA

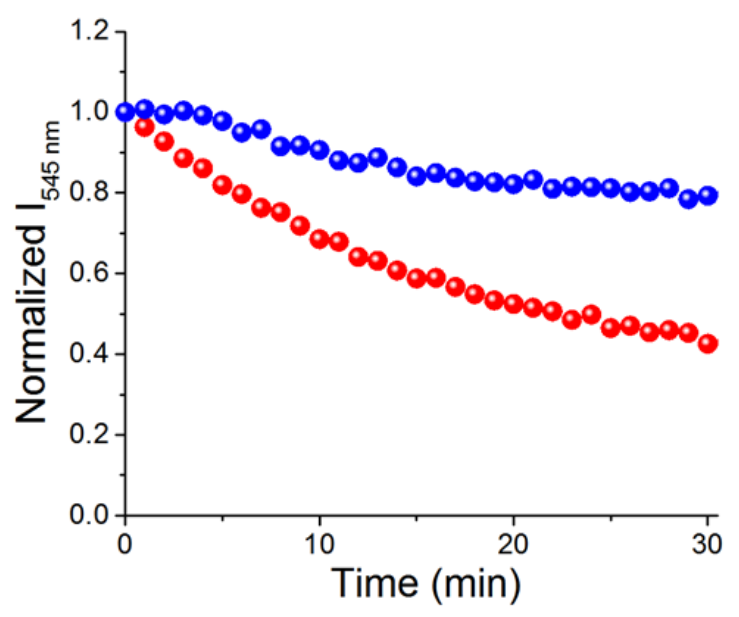

D) Cull release to EDTA

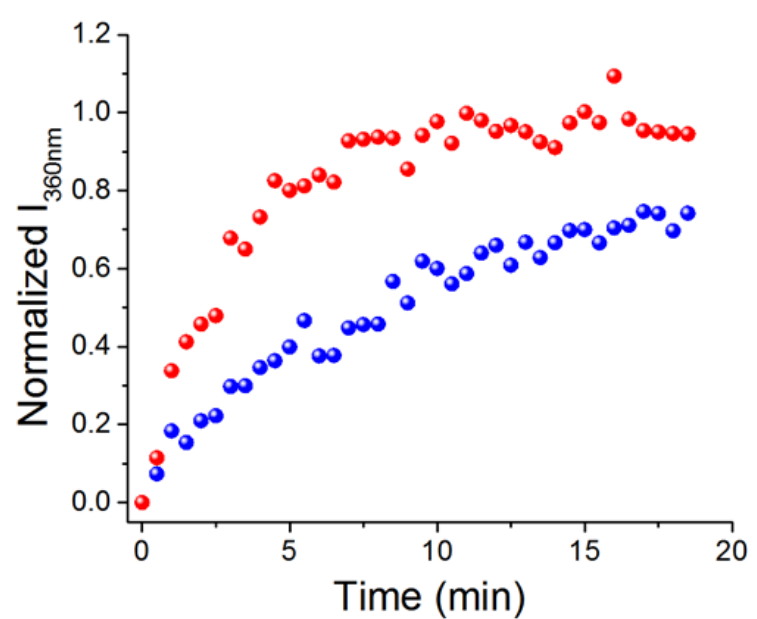

- $\mathrm{GNH}^{\mathrm{w} / \mathrm{Tb}}$

\section{$\mathrm{AHH}^{\mathrm{W} / \mathrm{Tb}}$}

Figure 3. Kinetics of $\mathrm{Cu}^{\mathrm{II}}$ transfer of $\mathbf{G N H}^{\mathrm{W} / \mathbf{T b}}$ (blue dots) and $\mathbf{A H} \mathbf{H}^{\mathbf{W} / \mathbf{T b}}$ (red dots). (A) kinetics of $\mathrm{Cu}^{\mathrm{II}}$ binding to the peptides in $10 \%$ LB medium; (B) kinetics of $\mathrm{Cu}^{\mathrm{II}}$ transfer from HSA to the peptides; (C) kinetics of $\mathrm{Cu}^{\mathrm{II}}$ binding to the peptides in $10 \% \mathrm{FBS}$; (D) kinetics of $\mathrm{Cu}^{\mathrm{II}}$ release from the peptides to EDTA. Conditions: $\left[\mathbf{G N H}^{\mathbf{W} / \mathbf{T b}}\right]=\left[\mathbf{A H H}^{\mathbf{W} / \mathbf{T b}}\right]=10 \mu \mathrm{M},\left[\mathrm{Cu}^{2+}\right]=9 \mu \mathrm{M},[\mathrm{HSA}]=10 \mu \mathrm{M}(\mathrm{B}),[$ EDTA $]=10 \mathrm{mM}(\mathrm{D})$, HEPES $50 \mathrm{mM}$ (B) or $100 \mathrm{mM}(\mathrm{D}), \mathrm{pH}$ 7.4. In (D), the signal of a peptide-EDTA solution (in absence of $\mathrm{Cu}^{2+}$ ) was subtracted. $\lambda_{\mathrm{ex}}=280 \mathrm{~nm}, \tau=0.1 \mathrm{~ms}$ in (A), (B) and (C); $\lambda_{\mathrm{ex}}=295 \mathrm{~nm}$ in (D). 
Moreover, these findings reveal that the apparent kinetics of $\mathrm{Cu}^{\mathrm{II}}$-binding to probes in biological media may be very different, specifically slower, in comparison to simple buffered aqueous solutions. Therefore, the kinetic responsiveness of a probe should be evaluated, along with the affinity, to define the appropriate timespan in which a sample has to be analysed.

Besides, we estimated the application range of the two probes in HEPES (100 mM, pH 7.4) and the biological media via calibration curves (see Table S1). In buffer, the limit of detection (LOD) of $\mathrm{Cu}^{\mathrm{II}}$-probe complexes resulted to be around $0.3 \mu \mathrm{M}$, while it was approximately 1 $\mu \mathrm{M}$ or higher in the media (albeit the LOD for $\mathbf{G N H}^{\mathrm{W} / \mathbf{T b}}$ in FBS resulted to be $0.46 \mu \mathrm{M}$ due to low standard deviation of the blank, the calibration curve showed poor linearity below $1 \mu \mathrm{M}$ $\mathrm{Cu}^{2+}$ and hence applications beneath such threshold are not recommended).

\subsection{Potential formation of ternary complexes in biological media}

The faster response shown by $\mathbf{A H} \mathbf{H}^{\mathbf{W} / \mathbf{T b}}$ may be due to the above-mentioned propensity of such ATCUN-like motif to form ternary complexes $(3 \mathrm{~N}+\mathrm{L})$ with external ligands provided by the media, such as free amino acids and protein residues.[24] For this reason, we examined whether $\mathbf{A H H}^{\mathbf{W} / \mathbf{T b}}$ formed stable ternary complexes in the media studied by luminescence. To assess the formation of a ternary complex between $\mathbf{A H} \mathbf{H}^{\mathbf{W} / \mathbf{T b}}$ and HSA we resorted to EPR spectroscopy. $\mathrm{Cu}^{\mathrm{II}}-\mathbf{A H H}{ }^{\mathrm{W} / \mathrm{Tb}}$ and $\mathrm{Cu}^{\mathrm{II}}$-HSA were barely distinguishable at low temperature (LT), as $\mathrm{Cu}^{\mathrm{II}}$ is bound with the same 4N ATCUN-type coordination (Fig. 4A) in both complexes, with characteristic EPR fingerprint ( $\mathrm{g}_{/ /} \approx 2.180$ and $\mathrm{A} / / \approx 600 \mathrm{MHz}$ ).[19] Instead, $\mathrm{Cu}^{\mathrm{II}}-\mathbf{A H H}{ }^{\mathrm{W} / \mathrm{Tb}}$ and $\mathrm{Cu}^{\mathrm{II}}-\mathrm{HSA}$ could be discriminated at room temperature (RT), where different EPR spectra can be obtained for complexes with the same coordination mode but different tumbling rate (Fig. 4B). [17] After incubation of $\mathrm{Cu}^{\mathrm{II}}$-HSA with $\mathbf{A H} \mathbf{H}^{\mathbf{W} / \mathbf{T b}}$, the mixture showed an RT-EPR spectrum (Fig. 4B, green curve) very similar to that of $\mathbf{C u}^{\mathrm{II}}-\mathbf{A} \mathbf{H} \mathbf{H}^{\mathbf{W} / \mathbf{T b}}$ (red curve), confirming that $\mathbf{A H} \mathbf{H}^{\mathbf{W} / \mathbf{T b}}$ retrieves $\mathrm{Cu}^{\mathrm{II}}$ from HSA (as observed by luminescence, Fig. 3A).
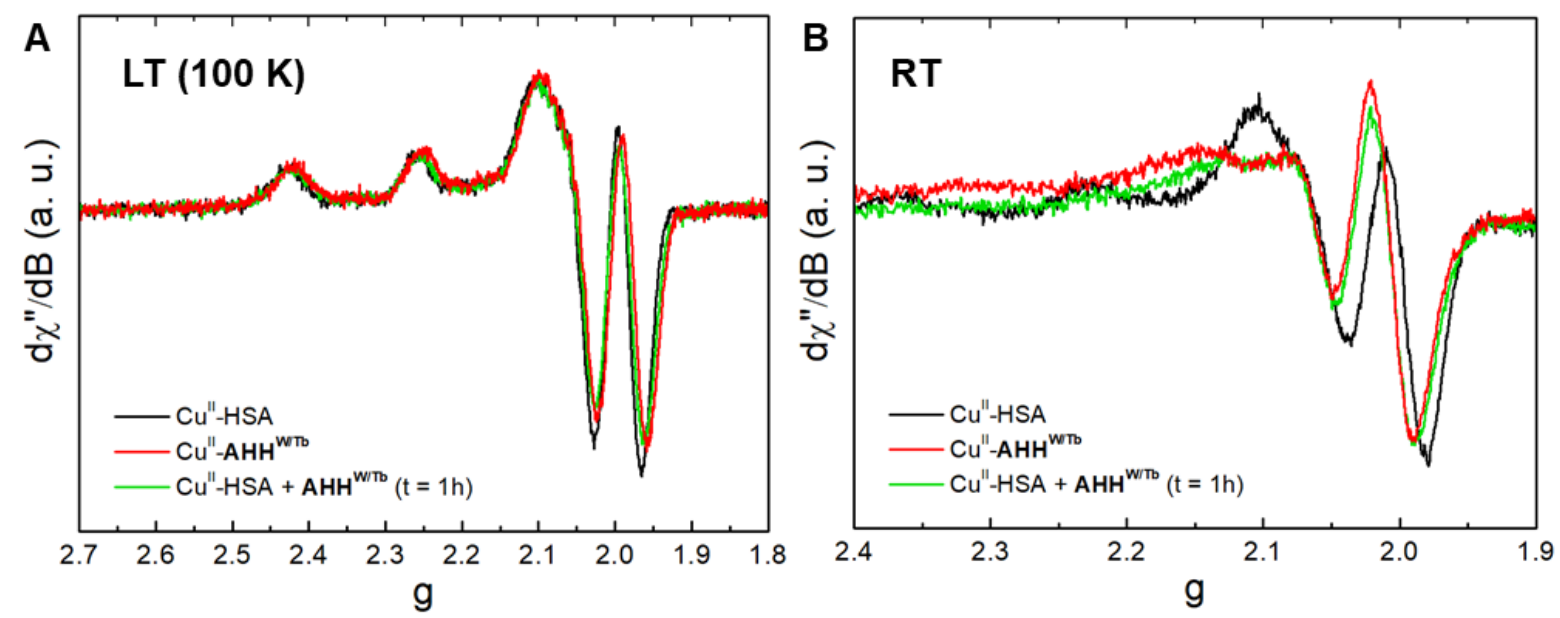

Figure 4. LT- (A) and RT- (B) EPR spectra of $\mathrm{Cu}^{\mathrm{II}}-\mathrm{HSA}$ (black curve), $\mathrm{Cu}^{\mathrm{II}}-\mathbf{A} \mathbf{H H}^{\mathrm{W} / \mathrm{Tb}}$ (red curve) and after $1 \mathrm{~h}$ incubation of $\mathrm{Cu}^{\mathrm{II}}$-HSA with $\mathbf{A H} \mathbf{H}^{\mathrm{W} / \mathbf{T b}}$ (green curve). Conditions: $[\mathrm{HSA}]=\left[\mathbf{A} \mathbf{H} \mathbf{H}^{\mathbf{W} / \mathbf{T b}}\right]=320 \mu \mathrm{M},\left[\mathrm{Cu}^{2+}\right]=300$ $\mu \mathrm{M}, 100 \mathrm{mM}$ HEPES pH 7.4. LT samples were supplemented by $10 \%$ (v/v) glycerol. All spectra were normalized.

Besides, the LT-EPR spectrum recorded after the $\mathrm{Cu}^{\mathrm{II}}$ transfer to $\mathbf{A H} \mathbf{H}^{\mathbf{W} / \mathbf{T b}}$ (Fig. 4A, green curve) was indistinguishable (within experimental error) from that of $\mathbf{C u}^{\mathrm{II}}-\mathbf{A H H}{ }^{\mathbf{W} / \mathbf{T b}}$ (red 
curve). This suggests that $\mathrm{Cu}^{\mathrm{II}}$ is bound in a $4 \mathrm{~N}$ ATCUN-type environment and no ternary $3 \mathrm{~N}+\mathrm{N}$ complex was formed between $\mathrm{Cu}^{\mathrm{II}}-\mathbf{A H} \mathbf{H}^{\mathbf{W} / \mathbf{T b}}$ and HSA. This finding is relevant as ternary complexes could affect the $\mathrm{Cu}^{\mathrm{II}}$-sensing by $\mathbf{A H} \mathbf{H}^{\mathbf{W} / \mathbf{T}}$.

Moreover, the potential formation of stable ternary complexes by $\mathrm{Cu}^{\mathrm{II}}-\mathbf{A H} \mathbf{H}^{\mathrm{W} / T \mathbf{T b}}$ in $\mathrm{LB}$ medium and FBS (10\%) was tested by UV-vis absorption, as the binding of external ligands to $\mathrm{Cu}^{\mathrm{II}}-$ $\mathbf{A H H}^{\mathbf{W} / \mathbf{T b}}$ induces a red-shift of the d-d band of such complex.[24] The d-d bands of $\mathrm{Cu}^{\mathrm{II}}$ $\mathbf{A H H}^{\mathbf{W} / \mathbf{T b}}$ in the media (see Fig. 5) were not significantly different from the d-d band of $\mathrm{Cu}^{\mathrm{II}}$ $\mathbf{A H H}^{\mathbf{W} / \mathbf{T b}}$ in $50 \mathrm{mM}$ HEPES (pH 7.4), excluding the formation of stable ternary complexes in such media (or rather excluding the formation of more and stronger ternary complexes than those potentially formed with the buffer itself). As a result, we speculate that the faster $\mathrm{Cu}^{\mathrm{II}}$ transfer showed by $\mathbf{A H} \mathbf{H}^{\mathbf{W} / \mathbf{T b}}$ compared to $\mathbf{G N H} \mathbf{W}^{\mathbf{W} / \mathbf{T b}}$ might be due to the lower activation energy required to reach the supposed transition state consisting of a short-lived ternary complexes. [27] For instance, histidine has been shown to fasten the transfer of $\mathrm{Cu}^{\text {II }}$ between HSA and EDTA.[30]

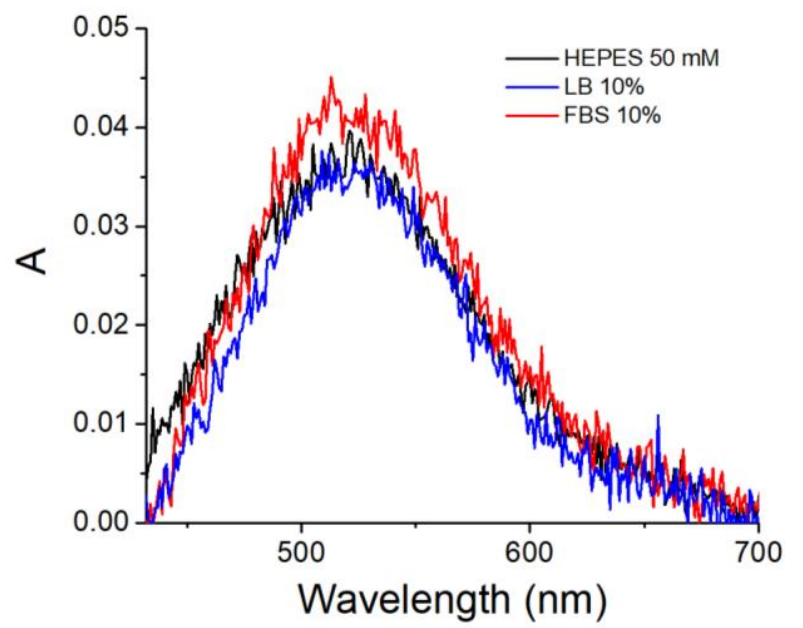

Figure 5. Visible spectra (d-d bands) of $\mathrm{Cu}^{\mathrm{II}}-\mathbf{A H} \mathbf{H}^{\mathrm{W} / \mathrm{Tb}}\left(\left[\mathbf{A H} \mathbf{H}^{\mathrm{W} / \mathrm{Tb}}\right]=500 \mu \mathrm{M},\left[\mathrm{Cu}^{2+}\right]=450 \mu \mathrm{M}\right)$ in HEPES 50 $\mathrm{mM}$ (black curve), 10\% LB medium (blue curve), 10\% FBS (red curve). Background spectra of the media with the peptide were subtracted.

\section{3. pH-dependence of the luminescence response}

The $\mathrm{pH}$ of some extracellular fluids may attain acidic values (e.g. down to $\approx 4.5$ in urine). In addition, $\mathrm{pH}$ fluctuations can occur. For this reason, we evaluated the $\mathrm{pH}$-dependence of $\mathrm{Tb}^{\mathrm{III}}$ luminescence in $\mathrm{Cu}^{\mathrm{II}}-\mathbf{A H} \mathbf{H H}^{\mathrm{W} / \mathbf{T b}}$ and $\mathrm{Cu}^{\mathrm{II}}-\mathbf{G N H}^{\mathrm{W} / \mathbf{T b}}$ complexes, as $\mathrm{Cu}^{\mathrm{II}}-\mathrm{XZH}$ complexes start dissociating at $\mathrm{pH}<\approx 5.5$ (see 1 . Introduction). The intensity of $\mathrm{Tb}^{\mathrm{III}}$ emission in $\mathrm{Cu}^{\mathrm{II}}-\mathbf{A H H} \mathbf{H}^{\mathbf{W} / \mathbf{T b}}$ was fairly constant between $\mathrm{pH} \approx 5$ and 7.5 , while it was approximately doubled at $\mathrm{pH} 4.6$ (see Fig. 6A). In $\mathrm{Cu}^{\mathrm{II}}-\mathbf{G N H}^{\mathrm{W} / \mathrm{Tb}}, \mathrm{Tb}^{\mathrm{III}}$ luminescence intensity was constant only between $\mathrm{pH} 6$ and 7.5 , as it is approximately doubled already at $\mathrm{pH} \approx 5$ (see Fig. 6B). This suggests that $\mathrm{Cu}^{\mathrm{II}}$ $\mathbf{G N H}^{\mathbf{W} / \mathbf{T b}}$ results partially dissociated at $\mathrm{pH} \approx 5$, while more $\mathrm{Cu}^{\mathrm{II}}$ remains bound to $\mathbf{A H} \mathbf{H}^{\mathbf{W} / \mathbf{T b}}$ at the same $\mathrm{pH}$. This trend is in agreement, as an example, with the different species distribution of AHH and AAH motifs (see Fig. S5).[23,31] In particular, by lowering the $\mathrm{pH}, \mathrm{Cu}^{\mathrm{II}}$-amidate bonds are the first to break, due to the high $\mathrm{p} K_{\mathrm{a}}$ of amides $(\approx 17)$. 

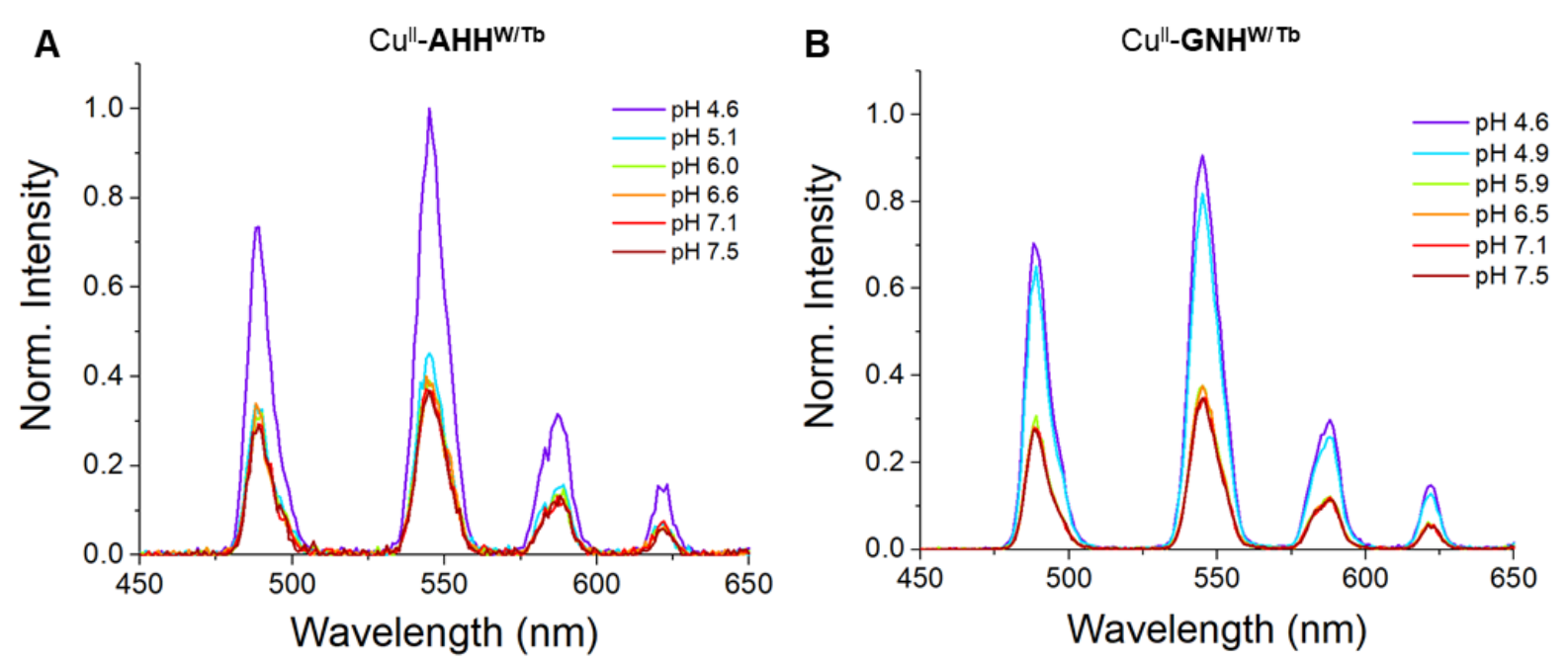

Figure 6. $\mathrm{pH}$-dependent $\mathrm{Tb}^{\mathrm{III}}$ luminescence in $\left.\mathrm{A}\right) \mathrm{Cu}^{\mathrm{II}}-\mathbf{A H} \mathbf{H}^{\mathrm{W} / \mathrm{Tb}}$ and $\left.\mathrm{B}\right) \mathrm{Cu}^{\mathrm{II}}-\mathbf{G N H}^{\mathrm{W} / \mathrm{Tb}}\left(\left[\mathbf{A H} \mathbf{H}^{\mathrm{W} / \mathrm{Tb}}\right]=\left[\mathbf{G N H}^{\mathrm{W} / \mathbf{T b}}\right]\right.$ $\left.=10 \mu \mathrm{M},\left[\mathrm{Cu}^{2+}\right]=9 \mu \mathrm{M} ; \lambda_{\mathrm{ex}}=280 \mathrm{~nm}, \tau=0.1 \mathrm{~ms}\right)$.

Thus, in the XZH motif $(\mathrm{Z} \neq \mathrm{H})$, the breakage of one $\mathrm{Cu}^{\mathrm{II}}$-amidate bond (any of the two) disrupts two (out of three) chelate rings, losing the high-affinity $4 \mathrm{~N}$ binding motif. Conversely, in the XHH motif, the protonation of one amide (from $\mathrm{His}^{3}$ ) allows a rearrangement to give the $3 \mathrm{~N}$ form (the imidazole ring of $\mathrm{His}^{2}$ replaces $\mathrm{His}^{3}$ amidate), which keeps two chelate rings, and hence still binds $\mathrm{Cu}^{2+}$ at $\mathrm{pH} \sim 5$ with $\log { }^{\mathrm{c}} K \approx 7$.

As a control, the luminescent response of the $\mathrm{Cu}$-free probes as a function of the $\mathrm{pH}$ was also evaluated (see Fig. S6). $\mathbf{G N H}^{\mathbf{W} / \mathbf{T b}}$ signal showed low $\mathrm{pH}$-dependence, whereas for $\mathbf{A H H} \mathbf{W}^{\mathbf{W} / \mathbf{T b}}$ $\approx 25 \%$ quenching was observed when the $\mathrm{pH}$ decreases from $\approx 7$ to $\approx 4.5$. This reveals that, despite the $\mathbf{A H} \mathbf{H}^{\mathbf{W} / \mathbf{T b}}$ variant can bind $\mathrm{Cu}^{2+}$ at lower $\mathrm{pH}$ than $\mathbf{G N H}{ }^{\mathbf{W} / \mathbf{T b}}$, it requires a $\mathrm{pH}-$ dependent calibration to compare samples with different $\mathrm{pH}$.

\section{Conclusion}

Here, we characterized the $\mathrm{Cu}^{\mathrm{II}}$ probe $\mathbf{A H} \mathbf{H}^{\mathbf{W} / \mathbf{T b}}$, a variant of the formerly reported $\mathbf{G N H}{ }^{\mathbf{W} / \mathbf{T b}}$. Both sensors used the $X x x-Z z z-H i$ is (ATCUN) motif, which binds $\mathrm{Cu}^{\mathrm{II}}$ selectively over the other essential metal ions and has a suited affinity to compete with endogenous ligands. In addition, $\mathbf{A H H}^{\mathbf{W} / \mathbf{T b}}$ and $\mathbf{G N H}^{\mathbf{W} / \mathbf{T b}}$ sensors were based on $\mathrm{Tb}^{\mathrm{III}}$ luminescence and hence profit from the narrow emission bands and long-lifetime emission, which helps to get rid of autofluorescence background in biological media by time-delayed measurements. On top of these common features, $\mathbf{A H} \mathbf{H}^{\mathbf{W} / \mathbf{T b}}$ is more kinetically competent to bind and release $\mathrm{Cu}^{\mathrm{II}}$, and $\mathrm{Cu}^{\mathrm{II}}-\mathbf{A} \mathbf{H} \mathbf{H}^{\mathbf{W} / \mathbf{T b}}$ appeared stable over a larger $\mathrm{pH}$ range. Moreover, no indication for ternary complexes and associated interference of the luminescence response to $\mathrm{Cu}^{\mathrm{II}}$ was observed, which would have been a potential drawback of $\mathbf{A H} \mathbf{H}^{\mathbf{W} / \mathbf{T b}}$ compared to $\mathbf{G N H}^{\mathbf{W} / \mathbf{T b}}$. Thus, besides its specificity and suited-affinity, $\mathbf{A H} \mathbf{H}^{\mathrm{W} / \mathrm{Tb}}$ provides faster response to $\mathrm{Cu}^{\mathrm{II}}$ in biological media. Furthermore, this study points out the importance of the $\mathrm{Cu}^{\mathrm{II}}$-transfer kinetics in biological media to the design of a ligand, e.g. a probe or a drug, for biomedical applications.

\section{Declaration of competing interest}

The authors declare no conflict of interest. 


\section{Acknowledgements}

The authors thank Dr. Loïc Charbonnière and Dr. Clémence Cheignon (UMR 7178, Strasbourg) for the access to the Tecan Spark plate reader, Prof. Paolo Samorì and Dr. Veronica Montes Garcia (ISIS, Strasbourg) for the access to the Agilent Cary Eclipse spectrofluorometer and Dr. Elise Glattard (UMR 7177, Strasbourg) for the preparation of LB medium. Dr. Olivier Sénèque (CEA, Grenoble) and Prof. Wojciech Bal (IBB, Warsaw) are acknowledged for helpful discussions. We also thank Michael Okafor for proofreading of the revised manuscript. E.F. is supported by the French National Research Agency (ANR) through the Programme d'Investissement d'Avenir under contract 17-EURE-0016. M. H. was supported by the EPIC Advantage internship grant via Earlham College, Indiana, USA.

\section{References}

[1] R.A. Festa, D.J. Thiele, Copper: An essential metal in biology, Curr. Biol. 21 (2011) R877-R883. https://doi.org/10.1016/j.cub.2011.09.040.

[2] P. De Bie, P. Muller, C. Wijmenga, L.W.J. Klomp, Molecular pathogenesis of Wilson and Menkes disease: Correlation of mutations with molecular defects and disease phenotypes, J. Med. Genet. 44 (2007) 673-688. https://doi.org/10.1136/jmg.2007.052746.

[3] P. Delangle, E. Mintz, Chelation therapy in Wilson's disease: From d-penicillamine to the design of selective bioinspired intracellular Cu(i) chelators, Dalt. Trans. 41 (2012) 6359-6370. https://doi.org/10.1039/c2dt12188c.

[4] S. Lutsenko, Copper trafficking to the secretory pathway, Metallomics. 8 (2016) 840852. https://doi.org/10.1039/c6mt00176a.

[5] A. Hordyjewska, Ł. Popiołek, J. Kocot, The many "faces" of copper in medicine and treatment, BioMetals. 27 (2014) 611-621. https://doi.org/10.1007/s10534-014-9736-5.

[6] D. Denoyer, S. Masaldan, S. La Fontaine, M.A. Cater, Targeting copper in cancer therapy: "Copper That Cancer," Metallomics. 7 (2015) 1459-1476. https://doi.org/10.1039/c5mt00149h.

[7] O. Bandmann, K.H. Weiss, S.G. Kaler, Wilson's disease and other neurological copper disorders, Lancet Neurol. 14 (2015) 103-113. https://doi.org/10.1016/S14744422(14)70190-5.

[8] E. Falcone, M. Okafor, N. Vitale, L. Raibaut, A. Sour, P. Faller, Extracellular Cu2+ pools and their detection: from current knowledge to next-generation probes, Coord. Chem. Rev. 433 (2021) Accepted. https://doi.org/10.1016/J.CCR.2020.213727.

[9] M.C. Linder, Ceruloplasmin and other copper binding components of blood plasma and their functions: An update, Metallomics. 8 (2016) 887-905. https://doi.org/10.1039/c6mt00103c.

[10] R. Squitti, R. Ghidoni, I. Simonelli, I.D. Ivanova, N.A. Colabufo, M. Zuin, L. Benussi, G. Binetti, E. Cassetta, M. Rongioletti, M. Siotto, Copper dyshomeostasis in Wilson disease and Alzheimer's disease as shown by serum and urine copper indicators, J. Trace Elem. Med. Biol. 45 (2018) 181-188. https://doi.org/10.1016/j.jtemb.2017.11.005.

[11] S. El Balkhi, J.M. Trocello, J. Poupon, P. Chappuis, F. Massicot, N. Girardot-Tinant, F. Woimant, Relative exchangeable copper: A new highly sensitive and highly specific biomarker for Wilson's disease diagnosis, Clin. Chim. Acta. 412 (2011) 2254-2260. https://doi.org/10.1016/j.cca.2011.08.019.

[12] S. Catalani, M. Paganelli, M.E. Gilberti, L. Rozzini, F. Lanfranchi, A. Padovani, P. 
Apostoli, Free copper in serum: An analytical challenge and its possible applications, J. Trace Elem. Med. Biol. 45 (2018) 176-180.

https://doi.org/10.1016/j.jtemb.2017.11.006.

[13] N. Solovyev, A. Ala, M. Schilsky, C. Mills, K. Willis, C.F. Harrington, Biomedical copper speciation in relation to Wilson's disease using strong anion exchange chromatography coupled to triple quadrupole inductively coupled plasma mass spectrometry, Anal. Chim. Acta. 1098 (2020) 27-36.

https://doi.org/10.1016/j.aca.2019.11.033.

[14] G. Sivaraman, M. Iniya, T. Anand, N.G. Kotla, O. Sunnapu, S. Singaravadivel, A. Gulyani, D. Chellappa, Chemically diverse small molecule fluorescent chemosensors for copper ion, Coord. Chem. Rev. 357 (2018) 50-104.

https://doi.org/10.1016/j.ccr.2017.11.020.

[15] E. Falcone, P. Gonzalez, L. Lorusso, O. Sénèque, P. Faller, L. Raibaut, A Terbium(III) luminescent ATCUN-based peptide sensor for selective and reversible detection of Copper(II) in biological media., Chem. Commun. 56 (2020) 4797-4800. https://doi.org/10.1039/d0cc01007c.

[16] T. Miyamoto, Y. Fukino, S. Kamino, M. Ueda, S. Enomoto, Enhanced stability of $\mathrm{Cu} 2+-A T C U N$ complexes under physiologically relevant conditions by insertion of structurally bulky and hydrophobic amino acid residues into the ATCUN motif, Dalt. Trans. 45 (2016) 9436-9445. https://doi.org/10.1039/c6dt01387b.

[17] K. Bossak-Ahmad, T. Frączyk, W. Bal, S.C. Drew, The Sub-picomolar Cu2+ Dissociation Constant of Human Serum Albumin, ChemBioChem. 21 (2020) 331-334. https://doi.org/10.1002/cbic.201900435.

[18] A.B. Uceda, L. Mariño, M. Adrover, B. Vilanova, Understanding metal binding in neuromedin C, Inorganica Chim. Acta. 499 (2020) 119197. https://doi.org/10.1016/j.ica.2019.119197.

[19] P. Gonzalez, K. Bossak, E. Stefaniak, C. Hureau, L. Raibaut, W. Bal, P. Faller, NTerminal Cu-Binding Motifs (Xxx-Zzz-His, Xxx-His) and Their Derivatives: Chemistry, Biology and Medicinal Applications, Chem. - A Eur. J. 24 (2018) 80298041. https://doi.org/10.1002/chem.201705398.

[20] I. Sóvágó, K. Várnagy, N. Lihi, Á. Grenács, Coordinating properties of peptides containing histidyl residues, Coord. Chem. Rev. 327-328 (2016) 43-54. https://doi.org/10.1016/j.ccr.2016.04.015.

[21] H. Kozłowski, T. Kowalik-Jankowska, M. Jezowska-Bojczuk, Chemical and biological aspects of $\mathrm{Cu} 2+$ interactions with peptides and aminoglycosides, Coord. Chem. Rev. 249 (2005) 2323-2334. https://doi.org/10.1016/j.ccr.2005.04.027.

[22] C. Harford, B. Sarkar, Amino Terminal Cu(II)- and Ni(II)-Binding (ATCUN) Motif of Proteins and Peptides: Metal Binding, DNA Cleavage, and Other Properties, Acc. Chem. Res. 30 (1997) 123-130. https://doi.org/10.1021/ar9501535.

[23] P. Gonzalez, B. Vileno, K. Bossak, Y. El Khoury, P. Hellwig, W. Bal, C. Hureau, P. Faller, $\mathrm{Cu}$ (II) Binding to the Peptide Ala-His-His, a Chimera of the Canonical Cu(II)Binding Motifs Xxx-His and Xxx-Zzz-His, Inorg. Chem. 56 (2017) 14870-14879. https://doi.org/10.1021/acs.inorgchem.7b01996.

[24] P. Gonzalez, K. Bossak-Ahmad, B. Vileno, N.E. Wezynfeld, Y. El Khoury, P. Hellwig, C. Hureau, W. Bal, P. Faller, Triggering Cu-coordination change in $\mathrm{Cu}(\mathrm{II})$ Ala-His-His by external ligands, Chem. Commun. 55 (2019) 8110-8113. https://doi.org/10.1039/c9cc03174j.

[25] D.L. Rabenstein, A.A. Isab, S.A. Daignault, A.P. Arnold, M.M. Shoukry, Nuclear Magnetic Resonance Studies of the Solution Chemistry of Metal Complexes. 21. The Complexation of Zinc by Glycylhistidine and Alanyihistidine Peptides, J. Am. Chem. 
Soc. 107 (1985) 6435-6439. https://doi.org/10.1021/ja00309a001.

[26] A. Santoro, N.E. Wezynfeld, E. Stefaniak, A. Pomorski, D. Płonka, A. Krężel, W. Bal, P. Faller, $\mathrm{Cu}$ transfer from amyloid- $\beta 4-16$ to metallothionein-3: the role of the neurotransmitter glutamate and metallothionein-3 $\mathrm{Zn}$ (II)-load states, Chem. Commun. 54 (2018) 12634-12637. https://doi.org/10.1039/c8cc06221h.

[27] R. Kotuniak, M.J.F. Strampraad, K. Bossak-Ahmad, U.E. Wawrzyniak, I. Ufnalska, P.L. Hagedoorn, W. Bal, Key Intermediate Species Reveal the Copper(II)-Exchange Pathway in Biorelevant ATCUN/NTS Complexes, Angew. Chemie - Int. Ed. 59 (2020) 11234-11239. https://doi.org/10.1002/anie.202004264.

[28] B. Chan, N. Dodsworth, J. Woodrow, A. Tucker, R. Harris, Site-specific N-terminal auto-degradation of human serum albumin, 528 (1995) 524-528.

[29] W. Bal, M. Sokołowska, E. Kurowska, P. Faller, Binding of transition metal ions to albumin: Sites, affinities and rates, Biochim. Biophys. Acta - Gen. Subj. 1830 (2013) 5444-5455. https://doi.org/10.1016/j.bbagen.2013.06.018.

[30] T. Kirsipuu, A. Zadorožnaja, J. Smirnova, M. Friedemann, T. Plitz, V. Tõugu, P. Palumaa, Copper(II)-binding equilibria in human blood, Sci. Rep. 10 (2020) 1-11. https://doi.org/10.1038/s41598-020-62560-4.

[31] J. Nagaj, K. Stokowa-Sołtys, I. Zawisza, M. Jezowska-Bojczuk, A. Bonna, W. Bal, Selective control of $\mathrm{Cu}$ (II) complex stability in histidine peptides by $\beta$-alanine, J. Inorg. Biochem. 119 (2013) 85-89. https://doi.org/10.1016/j.jinorgbio.2012.11.002. 